\title{
The Development of Practice in Permeation Grouting by using Fine- grained Cement Suspensions
}

\author{
Dimitrios Christodoulou ${ }^{1}$, Philotheos Lokkas ${ }^{2}$, Alexandros Droudakis ${ }^{3}$, Xenofon Spiliotis ${ }^{4}$, Dorothea \\ Kasiteropoulou ${ }^{5}$ and Nikolaos Alamanis ${ }^{6}$ \\ ${ }^{1}$ Department of Environmental Sciences, University of Thessaly \\ Larissa, Greece \\ Email: dchristo [AT] uth.gr \\ ${ }^{2}$ Emeritus Professor, University of Thessaly \\ Larissa, Greece \\ Email: p.lokkas [AT] uth.gr
}

${ }^{3}$ Ph.D. Civil Engineer, Geosynthetic Engineering Specialist, Technical Support Manager, Thrace Nonwovens \& Geosynthetics Xanthi, Greece

Adroudakis [AT] thraceplastics.gr

${ }^{4}$ Department of Environmental Sciences, University of Thessaly

Larissa, Greece

Email: spil [AT] uth.gr

${ }^{5}$ Department of Environmental Sciences, University of Thessaly

Larissa, Greece

Email: dkasiter [AT] uth.gr

${ }^{6}$ Department of Agriculture - Agrotechnology, University of Thessaly

Larissa, Greece

Email: alam [AT] uth.gr

\begin{abstract}
Grouting includes a range of processes that involve the injection of wet or dry materials into the ground to provide improved engineering properties. Common aims are to increase strength or stiffness or to reduce permeability within the mass of ground treated. This paper, mainly, addresses permeation grouting for the improvement of soils, in terms of strengthening or reduction of permeability, and compensation grouting for the displacement of structures during subsurface exploration. The grouts used to make permeation grouting are suspensions and chemical solutions. The suspensions penetrate well into soils with granulometry up to coarse sand. On the contrary, the chemical solutions penetrate satisfactorily in finer formations up to fine sands or coarse sludges. Because some chemical solutions are toxic or generally harmful to the environment and humans, an effort has been made internationally in recent years to replace them with inorganic fine-grained suspensions.
\end{abstract}

Keywords - Permeation Grouting, Fine-grained Cements, Suspensions, Injectability

\section{INTRODUCTION}

The design related on the shear behavior of a soil material is of particular interest because it has a direct impact on practical problems of bearing capacity $[1,2]$, stability of slopes and embankments $[3,4,5]$ as well as permanent seismic movements of slopes $[6,7,8]$. Various methods are used to improve the soils, such as: the lowering of the well horizon, the vibrational condensation, the dynamic condensation, the preloading and the injections. The category of injections includes: (a) permeation grouting, (b) compensation grouting, (c) condensation injections and (d) high pressure vein injections. Permeation grouting is one of the oldest methods for improving soil formations and have a wide range of applications [9]. According to Sudheer Kumar et. al. (2020), cement grouting technique is more efficient than compaction method [10]. In general, permeation grouting aim at increasing the shear strength, the density and the stiffness, along with a reduction of the compressibility and the soil permeability. The grouts used to perform permeation grouting, based on their composition, can be divided into: (a) Suspensions, (b) Solutions, (c) Emulsions and (d) Foams. In the category of suspensions belong these of clay and bentonite, the mixtures of bentonite-cement, pozzolanic-cement, Portland cement and fine-grained cements. Typical representatives of chemical solutions are sodium silicate, aminoplastics, phenoplastics, acrylics and acrylamides. The most popular emulsions are asphalt, a combination of asphalt - soap - casein in water, and asphalt with a suitable filler such as clay in water, which have been applied to soil stabilization and waterproofing 
problems. Foams include cement or clay-cement suspensions that can undergo a physical or chemical modification that creates air bubbles within them. Practically, and in terms of Engineering applications, the distinction has prevailed in the following types of grouts: (a) Cement grouts, (b) Fine cement grouts, (c) Fuel solutions and (d) Resins. Cement suspensions are low cost and environmentally friendly, but have a limited scope which reaches up to the coarse sands. On the contrary, chemical solutions can penetrate fine-grained sands or coarse-grained sludges, but they are more expensive and some of them are considered harmful to the environment and humans. With the aim of replacing these chemical solutions with suspensions that are harmless to the environment, but also equally effective in terms of their penetration into soil formations, efforts have been made to develop new suspension-type materials based on fine-grained cements. The MC-500 is the oldest fine-grained cement in the literature and appeared on the international market in the early 1980s. The volume of applications of fine-grained cements has been systematically increased over the last 20 years. Due to stricter environmental protection laws and lower costs against chemical solutions, fine-grained cements appear to be gradually replacing chemical solutions in the field of impregnation injections. Fine-grained cements have been used mainly to control groundwater flows and/or to improve soil strength, in applications including dams, tunnels, landfills, bridges and large construction projects.

\section{BACKROUND}

Injection is defined as the transmission process of a fluid material under pressure, to the required depth from the soil surface. The injection material, which is either a suspension of solid granules in water or a solution of chemicals, displaces the water from the soil pores and coagulates or solidifies in a short time.

\subsection{Injection categories}

The categories of injections as defined by European standards EN12715: 2000 and EN12716: 2000 are as follows: (a) Permeation Grouting, (b) Compensation Grouting and (c) Jet Grouting. The use of permeation grouting is a method of improving the properties and mechanical behavior of the soil. The method is generally expensive and its choice depends on the relative cost with respect to other alternative solutions. It is based on the replacement of water (or air) of soil voids or rock mass cracks by a grout, that is pressed under low pressure, so as not to disturb the soil formation. It is the oldest method of injection and is usually applied to relatively small areas of soil that are far from the soil surface. The method is used in technical projects, aiming at controlling underground flows, increasing the shear strength of soil formation, reducing deformation or subsidence and filling gaps [9].

\subsection{Historical background on Permeation Grouting}

The first application of injections mentioned in the international literature is credited to the French engineer Charles Berigny, who in 1802 used grouts of clay and calcium oxides to stabilize stone walls in the port of Dieppe, which had lost their strength due to corrosion between the stones. Through this method, named by him "procédé d' injection", the stabilization and reduction of the permeability of the local alluvial deposits was achieved. Portland cement was first injected in England in 1838 by Marc Isambard Brunel to build the first Thames tunnel, and in France by Collin (1839) to fill cracks in the body of the Grosbois Dam $[11,12]$. At the beginning of the $20^{\text {th }}$ century, due to the introduction of highpressure pumps and pressure gauges, the ability to control the permeation pressure and the flow of grout increased considerably, resulting in a significant improvement on the equipment for performing an injection program [12]. The development of railway networks in the first half of the last century led to the widespread use of cement injections, especially for the repair and strengthening on the foundations of railway bridges to cope with the increased loads of trains. With James Greathead as a pioneer, between 1900 and 1930, mechanical systems and pumps were developed, capable of pumping high-pressure cement injection material deep into the ground. Through this way, problems related to the large dams that began to be built at that time and particularly problems of controlling the underground flows and strengthening the supports of the dams were solved [13]. Along with the development of the injection's technique with cement grouts, the first injection materials based on chemicals in solution form began to appear. The first application of injections using a chemical solution (concentrated sodium silicate) was attributed to Jeriorsky, who introduced a "twostage" injection method and for this reason he was awarded a patent in 1886 [11, 12]. In 1909 Lemaire and Dumont proposed a "one-step" chemical injection method with a dilute solution of silicon and acid, which, however, in application, presented significant practical problems. In 1925, the Dutchman Joosten perfected the "two-stage" method based on sodium hydrated silicate and extended its scope to soils with fine sand granulometry. The system introduced by Joosten was widely used in the construction of the Berlin Underground in the 1930s. An important impetus to the application of injections was given in 1933 by the invention of the "tube-à-manchette" (TAM) by the Swiss engineer Ischy, which allows the permeation of grouts with different properties, in any order at any step of time in the same drilling [11, 12]. In 1934 Mayer developed a "one-step" method by which he was able to control the curing time of the silicate suspension by helping to solve some of the practical problems of Joosten's method. Reports of cement grouts injections are also related to the construction of the Estacada Dam barrier wall in Oregon, USA (1910-1912). The construction of the Hoover Dam (1932-1936), however, was the first large-scale application of cement injections for stabilization and contributed decisively to the development of the existing knowledge for the time. A significant improvement in grout quality was provided by the colloidal mixer invented in 1934 by J.P. Morgan and was marketed in 
England in 1937 by Colcrete. The rapid mixing achieved, resulted in the removal of air from the grout, improved hydration and increased the amount of fine cement grains. This resulted in the possibility of making grouts with a lower water to cement ratio (W/C), with less exudation and higher strength. This type of mixer is still used today [11]. During World War II (1939-1945) there was, as expected, a slowdown of growth in the field of injections. After its end, however, a rapid progress was made, especially in the field of chemical solutions. Very important is the invention of an acrylic chemical solution (AM-9) by Mello, Hauser and Lambe in 1953, which presented a slightly higher viscosity than water, had the ability to penetrate muddy soils and provided excellent curing time $[12,13,14]$. In the early 1980 s, this solution was replaced by less toxic chemical solutions with AC-400 as their main representative. Soletanche in 1957 developed a "hard" silicate solution using an organic ester capable of delivering sand resistances of 2-3 MPa [12]. From 1980 onwards, a shift was realized in technological development, towards a limitation on the use of chemical solutions, along with the development of new non-toxic materials, consisting of inorganic components that are less harmful to the natural environment $[12,15,16,17,18,19]$.

\section{SUSPENSION-TYPE GROUTS}

The most popular suspension - type grouts are those based on cement, whose main components are the common Portland cement and water. Depending on the needs of each application (high initial strength, resistance to chemical environment) it is possible to use different types of cement (aluminum, slag, etc.) instead of common cement. In addition, it is possible to add to the grouts some solids (sand, clay) with the main purpose of reducing the cost of injections, while the use of admixtures such as fly ash, slag silica fume and addition of chemical improvers (i.e. water reducers, superplasticizers, coagulation accelerators etc.) aims to improve some properties.

\subsection{Water}

The quality of the water, used to make the cement grouts, should be controlled from the beginning because it is an important parameter of their composition. Generally, drinking water is considered suitable for the preparation of cement grouts [11]. According to Van der Stoel [12], the $\mathrm{pH}$ value is the regulatory factor on the basis of which the choice should be made. This is based on the fact that the acidity of the water affects the setting time of the grouts. He argues, in fact, that when $\mathrm{pH}$ values range from 6 to 8 , the effect of acidity is considered negligible. Also, water, which contains sulfates $(>0.1 \%)$, chlorine $(>0.5 \%)$, sugars, suspended solids especially organic, or presents a high alkali content, is dangerous, especially for applications with high strength requirements in the presence of steel.

\subsection{Cement}

Cement is a mortar, which, when mixed with water, can thicken and harden both in air and in water. It is mainly an excellent hydraulic mortar, which combines high hydraulicity and strength. Common Portland cements are mainly used for permeation grouting. The raw materials, which are necessary for the preparation of the main phases of Portland cements, are those that contain the oxides of calcium $(\mathrm{CaO})$, silicon $\left(\mathrm{SiO}_{2}\right)$, aluminum $\left(\mathrm{Al}_{2} \mathrm{O}_{3}\right)$ and iron $\left(\mathrm{Fe}_{2} \mathrm{O}_{3}\right)$. Limestone gives $\mathrm{CaO}$, while clay gives $\mathrm{SiO}_{2}, \mathrm{Al}_{2} \mathrm{O}_{3}$ and $\mathrm{Fe}_{2} \mathrm{O}_{3}$. Marls contain all four oxides in varying amounts depending on their composition. Furthermore, silica sand contains $\mathrm{SiO}_{2}$ and bauxite $\mathrm{Al}_{2} \mathrm{O}_{3}$. The main phases of Portland type cements are the following [20]: (a) $\mathrm{C}_{3} \mathrm{~S}$ silica, (b) Calcium silicate $\mathrm{C}_{2} \mathrm{~S}$, (c) $\mathrm{C}_{3} \mathrm{~A}$ alumina and (d) Aluminum-iron calcium $\mathrm{C}_{2}(\mathrm{~A}, \mathrm{~F})$. The above phases are not present in the cements completely pure, but with small admixtures of $\mathrm{MgO}$, $\mathrm{TiO}_{2}, \mathrm{~K}_{2} \mathrm{O}, \mathrm{Na}_{2} \mathrm{O}, \mathrm{Mn}_{2} \mathrm{O}_{3}$ etc. Portland cement consists of clinker and gypsum (or gypsum and anhydride), which are collected in a very fine powder with a special surface of Blaine $2200-6000 \mathrm{~cm}^{2} / \mathrm{gr}$. The amount of gypsum that grinds together with the clinker depends on the fineness and type of cement and is necessary to regulate the setting. However, for reasons of volume stability, the amount of cement must be limited. Clinker is a product of firing (shells or extruders) of blast furnaces and the materials from which it is made are usually limestone and clay or marls that contain both materials. To improve the proportions of the firing mixture, silica sand and iron oxides can be added [20]. Cements have standard mechanical, chemical and physical properties, which are determined by performing standard tests. According to the European Standard EN 197-1: 2000, these properties are: strength after 2, 7 and 28 days, the initial setting time and the swelling after setting. Important properties of Portland cements are also Blaine fineness, density and loose weight. The most important property for choosing the right cement for injections is its fineness, which is expressed by the special Blaine surface (in $\mathrm{cm}^{2} / \mathrm{gr}$ and $\mathrm{m}^{2} / \mathrm{gr}$ ). The finer the cement is ground, the larger the surface to react with water and therefore the reaction (hydration) takes less time. The cement grains react with the water on their surface and this reaction proceeds gradually towards the center, until the grain is completely hydrated. If the fineness is low, the cement grains are not fully hydrated, while in cements with very high fineness we have the appearance of cracks in the hardened cement paste. The German Regulations define only a lower limit (minimum limit) for fineness at $2200 \mathrm{~cm}^{2} / \mathrm{gr}$ [20]. In general, in common Portland cements the fineness ranges from 350 to $800 \mathrm{~m}^{2} / \mathrm{gr}$ [16]. However, the fineness is not enough to ensure the optimal choice of cement, but should be combined with the knowledge of its granulometric curve. Most common cements have a maximum grain diameter ranging from 50 to $200 \mu \mathrm{m}$, thus limiting the scope of application of cement injections in coarse-grained soils with $D_{10} \geq 1 \mathrm{~mm}$ and $\mathrm{k} \geq 5 \cdot 10^{-2} \mathrm{~cm} / \mathrm{sec}$ and in rocks presenting cracks of thickness $\alpha \geq$ $160 \mu \mathrm{m}$ [21]. Due to these limitations, arose the need for the production of new fine-grained cements that would be the basis for the preparation of grouts with improved properties, able to penetrate into finer formations. 


\subsection{Additives}

Additives are natural or artificial materials that are added to cement grouts to improve certain properties and/or reduce their manufacturing costs. In the international literature they appear under various terms and mainly with the term "fillers" and are divided into non-active materials that are inert (sands, clays) and pozzolans and chemical property improvers that are active ingredients [21, 22, 23, 24].

\section{FINE-GRAINED CEMENTS}

Common cement-based suspensions -as defined by the various standards (ASTM C 150-04, EN 197-1: 2000, etc.)- are capable of penetrating coarse-grained soil materials effectively (e.g. gravel and coarse-grained sands) with a permeability of $10^{-1} \mathrm{~cm} / \mathrm{sec}$ and above [25]. Various types of chemical solutions are used to reinforce lower permeability soils (up to $10^{-4} \mathrm{~cm} / \mathrm{sec}$ ) that can penetrate into soil formations such as fine sands and sludges. However, it has been shown that materials of this type have significant disadvantages, such as high cost, unsatisfactory durability, low strength and can also cause environmental pollution due to their toxicity [14, 25, 26, 27]. In the last thirty years, new materials have been developed, which are presented as a counter-proposal to the use of chemical solutions for the above problems. These are extremely fine-grained cements whose suspensions have the ability to penetrate and reinforce even fine-grained sands $[17,28,29,30,31,32,33,34]$. The main advantage of these materials over chemical solutions is that they are composed entirely of minerals and thus do not cause adverse environmental effects.

\subsection{Definition}

For the reinforcement of soils, characterized as medium or fine-grained sands, various types of solutions have been developed in the last thirty years that are able to penetrate effectively into soil formations with a permeability coefficient of up to $10^{-4} \mathrm{~cm} / \mathrm{sec}$. These solutions, which are mainly chemical, have significant disadvantages associated with high cost, unsatisfactory durability and environmental impact due to their toxic behavior $[13,25,26]$. On the other hand, mortars developed on the basis of common cements can penetrate effectively into coarse-grained soils (e.g. gravelly and coarse-grained sands) with a permeability of $10^{-1} \mathrm{~cm} / \mathrm{sec}$ [25]. Therefore, in order to achieve satisfactory penetration with the least possible impact on the natural environment, the use of fine-grained cements for the preparation of suspensions that are capable to permeate fine-grained formations has been proposed in recent years $[9,17,28]$.

\subsection{Categorization of fine-grained cements}

The categorization of cements into "fine-grained" along with their clear separation is based on the establishment of certain criteria and standards that are applied. The Norwegian standard separates the fine-grained cements into: microfine with $\mathrm{d}_{95}<30 \mu \mathrm{m}$ and ultrafine with $\mathrm{d}_{95}<15 \mu \mathrm{m}$ [23]. In the USA, according to the ACI Committee 552, fine-grained cements are those that show a maximum grain size, $\mathrm{d}_{\max }=15 \mu \mathrm{m}$ [35], while the European standard EN 12715: 2000, defines as fine-grained (microfine cements) those with $d_{95}<20 \mu \mathrm{m}$ and Blaine fineness $>8000 \mathrm{~cm}^{2} / \mathrm{gr}$. Finally, in Britain, ultrafine cements are defined those having a maximum diameter of grain $d_{\max }<6 \mu \mathrm{m}[11]$

\subsection{Methods of preparation}

The preparation of suspensions from fine-grained cements is carried out by two methods: the dry and the wet grinding process [36]. Most fine-grained cements are produced by the dry method and are products of grinding Portland common cement, blast furnace slag or some pozzolan. Grinding takes place in special mills, in which the size of the maximum grain is reduced [24]. The second method of making fine-grained cements, referred to in the literature as the wet method, grinds the cement in mills in the presence of water, on site. Efforts in this direction have led to the production of suspensions called Microsol [25] and Cemill [27], although there are other standard methods of preparing suspensions, such as Ahrens (1997) [38] and Huang et al. (2002) [36]. However, Cemill suspensions appear to have a very short workability and require a complex manufacturing process, while Ahrens suspensions do not exhibit satisfactory rheological properties and result from extremely slow process [24]. Naudts and Landry in 2003 [39] introduced the PASREM grinding machine which enables the preparation of suspensions in a short period of time along with satisfactory rheological properties. In general, the wet method allows the production of the desired amount of suspension by reducing waste, favors more accurate project budgets and requires much lower costs compared to the preparation of fine-grained cements with the dry method. However, it does not allow the production of materials with a maximum grain size of less than $18 \mu \mathrm{m}$ [39].

\subsection{Fine-grained cements as commercial products}

Table 1 below gives the trade names of some fine-grained cements and their characteristics, based on the existing information from the international literature. The MC-500 is the oldest fine-grained cement in the international literature and is produced by the Japanese cement company Onoda Cement. Following the absorption of the company by Taiheiyo Materials, this product is available in the market of Southeast Asia and Australia under the brand name Alofix MC, while in the USA under the name MC-500. It is a mixture of finely ground Portland cement and slag in a ratio of 4:1 [40], which consists only of minerals and has a specific gravity of $3.0 \pm 0.1 \mathrm{gr} / \mathrm{cm}^{3}$. Its manufacturers recommend its combined 
use with the NS-200 hyperplasticizer at a dose of 2\% by weight of dry cement. From Figure 1 it yields that MC-500 / Alofix MC based cement suspensions can achieve penetration comparable to that of chemical solutions. SuperFine and SuperFine-L are fine-grained, slag cements manufactured by the Japanese company Nittetsu. They have an average grain size of $3 \mu \mathrm{m}$ and a specific gravity of $3.0 \mathrm{gr} / \mathrm{cm}^{3}$ and $2.92 \mathrm{gr} / \mathrm{cm}^{3}$, respectively [19]. The use of Nittetsu SuperFine has been reported by several researchers $[41,42,43]$. Clarke introduced later the MC-500 to the U.S.A. under the trade name M5 and then manufactured M1 and M3 cements [44, 45, 46], giving them the trade names MC-100 and MC-300 respectively. MC-100 is a fine-grained slag, while MC-300 is a fine-grained Portland cement [47, 48, 49].

Table 1: Trade names and characteristics of fine-grained cements

\begin{tabular}{|c|c|c|c|c|}
\hline $\begin{array}{l}\text { Commercial } \\
\text { Designation }\end{array}$ & Manufacturer & $\begin{array}{l}\text { Country of } \\
\text { origin }\end{array}$ & $\begin{array}{l}\text { Fineness by } \\
\text { Blaine } \mathbf{m}^{2} / \mathbf{k g r}\end{array}$ & $\begin{array}{l}\text { Feature Size } \\
\text { Granules } \mu \mathrm{m}\end{array}$ \\
\hline * MC-500 / Alofix MC & Taiheiyo Materials & Japan & $>800$ & $\mathrm{~d}_{\max }=15$ \\
\hline$\$ \mathrm{MC}-300$ & \multirow{2}{*}{$\begin{array}{l}\text { DeNeef } \\
\text { (Taiheiyo Materials) }\end{array}$} & \multirow{2}{*}{ U.S.A. } & $>1300$ & $\mathrm{~d}_{\max }<40$ \\
\hline \# MC-100 & & & $>1200$ & $\mathrm{~d}_{\max }=8$ \\
\hline \$ Microblend A & \multirow{2}{*}{$\begin{array}{l}\text { Microblend } \\
\text { Solutions Inc. }\end{array}$} & \multirow{2}{*}{ Canada } & $>1200$ & $\mathrm{~d}_{\max }<20$ \\
\hline Microblend AF & & & $>1200$ & $\mathrm{~d}_{\max }<20$ \\
\hline${ }^{*}$ Spinor A6 & \multirow{3}{*}{$\begin{array}{l}\text { Ciment d' Origny } \\
\text { (Holcim Group) }\end{array}$} & \multirow{3}{*}{ France } & & $\mathrm{d}_{98}=6$ \\
\hline * Spinor A12 & & & $>1000$ & $\mathrm{~d}_{98}=12$ \\
\hline * Spinor A16 & & & 1200 & $\mathrm{~d}_{98}=16$ \\
\hline MC $20 \mathrm{RS}$ & Holcim Brazil & Brazil & & $\mathrm{d}_{98}=20$ \\
\hline * Fine Hard & Mitsubishi Materials & Japan & 1260 & $\mathrm{~d}_{\max }=12$ \\
\hline Micromix & & & 1200 & $\mathrm{~d}_{\max }=10$ \\
\hline \# Mikrodur R-F & \multirow{5}{*}{ Dyckerhoff AG } & \multirow{5}{*}{ Germany } & 1200 & $\mathrm{~d}_{95}=16$ \\
\hline \# Mikrodur R-U & & & 1600 & $\mathrm{~d}_{95}=9.5$ \\
\hline " Mikrodur R-X & & & 1900 & $\mathrm{~d}_{95}=6$ \\
\hline \$ Mikrodur P-F & & & 1200 & $\mathrm{~d}_{95}=16$ \\
\hline \$ Mikrodur P-U & & & 1600 & $\mathrm{~d}_{95}=9.5$ \\
\hline$\$$ Microcem A & \multirow{2}{*}{$\begin{array}{l}\text { Addiment } \\
\text { (Sika AG) }\end{array}$} & \multirow{2}{*}{ Germany } & 1400 & $\mathrm{~d}_{95}=9$ \\
\hline$\$$ Microcem B & & & 1500 & $\mathrm{~d}_{98}=8$ \\
\hline Type V Premium & \multirow{2}{*}{ U.S Grout } & \multirow{2}{*}{ U.S.A. } & 1710 & $\mathrm{~d}_{90}<5$ \\
\hline Type V Standard & & & 1510 & $\mathrm{~d}_{90}<8$ \\
\hline * Superfine & \multirow{2}{*}{ Nittetsu Cement Co. } & \multirow{2}{*}{ Japan } & $>900$ & $\mathrm{~d}_{\max }=10$ \\
\hline * Superfine-L & & & $>900$ & $\mathrm{~d}_{\max }=10$ \\
\hline Micro A & \multirow{3}{*}{$\begin{array}{l}\text { Ube Industries Ltd. } \\
\text { Cement Division }\end{array}$} & \multirow{3}{*}{ Japan } & 1010 & $\mathrm{~d}_{98}=20$ \\
\hline Micro N & & & 990 & $\mathrm{~d}_{98}=20$ \\
\hline Micro S & & & 1020 & $\mathrm{~d}_{98}=20$ \\
\hline \$ Rheocem 650 & \multirow{3}{*}{$\begin{array}{l}\text { BASF } \\
\text { Chemicals }\end{array}$} & \multirow{3}{*}{ Switzerland } & $>625$ & $\mathrm{~d}_{95}<15$ \\
\hline \$ Rheocem 800 & & & $>800$ & $\mathrm{~d}_{98}<15$ \\
\hline \$ Rheocem 900 & & & $>900$ & $\mathrm{~d}_{98}<10$ \\
\hline \$ Ultrafin 12 & \multirow{2}{*}{$\begin{array}{l}\text { Cementa AB } \\
\text { (HeidelbergCement) }\end{array}$} & \multirow{2}{*}{ Sweden } & 2200 (BET) & $\mathrm{d}_{95}=12$ \\
\hline \$ Ultrafin 16 & & & $>800$ & $\mathrm{~d}_{95}=16$ \\
\hline Micro Matrix & Halliburton & U.S.A. & $>900$ & $\mathrm{~d}_{98}=15$ \\
\hline
\end{tabular}

Cement based on: \$ Portland, * slag, * Portland + slag 


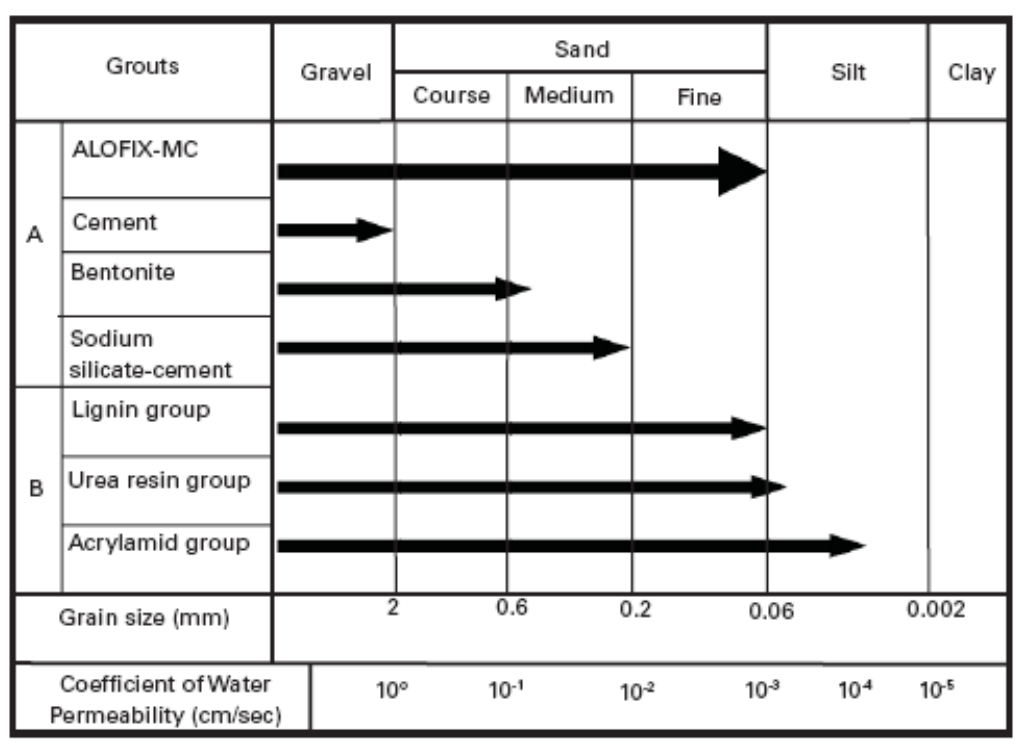

Figure 1: Comparison of the penetration of MC-500 / Alofix MC cement suspensions with other grouts [50]

The U.S. Company Grout prepares cement-based injection materials by both dry and wet methods. The fine-grained cements Type V Premium and Type V Standard have a specific weight of $2.63 \mathrm{gr} / \mathrm{cm}^{3}$ and $2.70 \mathrm{gr} / \mathrm{cm}^{3}$ and an average grain size of $2.50 \mu \mathrm{m}$ and $4.0 \mu \mathrm{m}$, respectively. Their chemical composition includes $55 \%$ Thera earth and $45 \%$ super grounded type IV Portland cement. In the dry state, their combined use with a hyperplasticizer in doses of $1.5 \%$ and $2.5 \%$ by weight respectively of dry cement is required. The specific materials are the basis for the production of suspensions with a ratio W/C of 0.6:1 and 0.8:1, respectively, following the wet method and a very specific process in terms of the manner and time of mixing and stirring. The use of Type V Premium cement is noted in their research efforts by Henn et al., (2001) [41] and Henn et al., (2005) [42]. Important references in the international literature are related to the Spinor cements (A6, A12 and A16) of the French company Soletanche-Bachy [15, 51]. Their main representative is the finegrained cement A12, which is slag having a specific weight of $2.94 \mathrm{gr} / \mathrm{cm}^{3}$. The manufacturer proposes the use of a superplasticizer in a dosage of $3 \%$ by weight of dry cement along with W/C ratios from 1:1 to 3:1. Spinor A12 can also be used for the preparation of Microsol grouts, which are prepared by the wet method. It is also reported that MC $20 \mathrm{RC}$ fine cement is manufactured in Brazil by Holcim Brazil [52]. A significant part of the international market is occupied by fine-grained cements under the brand name Mikrodur, which are sold by Dyckerhoff AG. These are products consisting of either pure Portland (with the mark P) or pure slag (with the mark R). Finosol products are also available from the same company, which are suspensions resulting from the mixing of blast furnace slag, clinker, coagulation and admixtures controller in field applications.

Characteristic of these suspensions is the individual preparation of their ingredients before the final mixing. Depending on their fineness, Mikrodur and Finosol materials are divided into F (Fine), U (Ultrafine) and X (EXtrafine). Mikrodur and Finosol cements have been used in various research efforts [25, 53, 54, 55]. Products of the company BASF Construction Chemicals are the fine-grained cements under the brand name Rheocem, which are based on pure Portland cement. Depending on their fineness, they are divided into products 650, 800 and 900 [56]. The manufacturer recommends their use in combination with the plasticizer Rheobuild 2000PF in a dosage ranging from $1.0 \%$ to $3.0 \%$ by weight of dry cement. Henn et al. (2001) [41], used in field applications, suspensions based on the fine-grained Microcem A and Microcem B cements of Addiment company. These are fine-grained pure Portland cements that have a specific weight of $3.20 \mathrm{gr} / \mathrm{cm}^{3}$. The Swedish company Cementa $\mathrm{AB}$ is also active in the production of fine-grained cements, introducing on the market the fine-grained cements Ultrafin 12 and Ultrafin 16 with a specific weight of $3.10-3.20$ $\mathrm{gr} / \mathrm{cm}^{3}$. The Norwegian company Elkem ASA Materials proposes the product Ultrafin 12 as a basis for the preparation of fine-grained suspensions available in the market under the brand name MultiGrout System. The Cemill designation identifies the wet method by which cement suspensions are prepared on site using Portland conventional cement as a base. The method was proposed by De Paoli et al. (1992b) [37] and aims at developing an on-site production process of fine-grained material using common cement. This process made it possible to produce not only unstable grouts (CemillI), but also fixed grouts using bentonite (Cemill-S). These objectives were achieved with a special device, which has two functions: (a) achieves very strong dispersion of cement granules without the addition of a corresponding anticoagulant and (b) implements a progressive procedure of elaborating the coarse cement fraction until it reaches the desired levels of fineness without the need for this coarse material to be removed [37]. Regarding the chemical composition of finegrained cements, it is emphasized that, mainly, they consist of the same oxides as Portland cements, but in different proportions. Another element, which promotes the use of fine-grained cements for permeation injections, is the fact that they are composed of inorganic and non-toxic materials, an element that is particularly beneficial in preventing 
environmental pollution. Table 2 below gives typical chemical compositions of commercially available fine-grained cements, while Table 3 lists characteristic cases of use for fine-grained cement grouts.

Table 2: Typical chemical compositions of fine-grained cements

\begin{tabular}{|c|c|c|c|c|c|c|}
\hline $\begin{array}{l}\text { Chemical } \\
\text { Ingredient }\end{array}$ & $\begin{array}{l}\mathrm{SiO}_{2} \\
(\%)\end{array}$ & $\begin{array}{l}\mathrm{Al}_{2} \mathrm{O}_{3} \\
(\%)\end{array}$ & $\begin{array}{l}\mathrm{Fe}_{2} \mathrm{O}_{3} \\
(\%)\end{array}$ & $\begin{array}{l}\mathrm{CaO} \\
(\%)\end{array}$ & $\begin{array}{l}\text { MgO } \\
(\%)\end{array}$ & $\begin{array}{l}\mathrm{SO}_{3} \\
(\%)\end{array}$ \\
\hline MC-100 & 35.4 & 16.0 & 0.3 & 43.3 & 3.5 & 0.3 \\
\hline MC-300 & 17.9 & 4.9 & 3.5 & 61.6 & 2.6 & 2.4 \\
\hline MC-500 & 29.0 & 13.2 & 1.2 & 49.2 & 5.6 & 1.2 \\
\hline Fine Hard & 31.6 & 13.6 & 0.7 & 46.4 & 6.1 & 1.6 \\
\hline Micro A & 28.8 & 11.3 & 1.0 & 48.9 & 5.4 & 1.4 \\
\hline Micro N & 30.9 & 12.9 & 0.5 & 44.3 & 6.3 & 1.6 \\
\hline Micro S & 26.9 & 10.4 & 1.4 & 51.1 & 4.6 & 2.0 \\
\hline Spinor A12 & 31.0 & 9.5 & 1.3 & 44.0 & 6.5 & \\
\hline MC $20 \mathrm{RS}$ & 24.3 & 7.7 & 2.0 & 52.7 & 3.8 & 3.7 \\
\hline Micro Matrix & 20.4 & 6.4 & 2.7 & 62.3 & 1.0 & 3.3 \\
\hline
\end{tabular}

Table 3: Typical cases of use for fine-grained cement grouts

\begin{tabular}{|c|c|c|c|c|}
\hline Reference & Cement & Work & $\begin{array}{l}\text { Soil } \\
\text { Formation }\end{array}$ & Target \\
\hline \multirow{3}{*}{$\begin{array}{l}\text { Shimoda and } \\
\text { Ohmori, } 1982\end{array}$} & $\mathrm{MC}-500$ & Railway tunnel & Loose volcanic gravel & ${ }^{*} \mathrm{C},{ }^{\#} \mathrm{~S}$ \\
\hline & MC-500 & Tunnel & Fine sand & $\mathrm{S}$ \\
\hline & $\mathrm{MC}-500$ & Dam & Branched granite & $\mathrm{S}$ \\
\hline Moller et al., 1983 & $\mathrm{MC}-500$ & Tunnel & Branched granite & $\mathrm{C}$ \\
\hline Clarke, 1984 & $\mathrm{MC}-500$ & Tunnel & Branched granite & $\mathrm{C}$ \\
\hline Dasika, 1985 & MC-500 & Building & Sand & $\mathrm{S}$ \\
\hline Winter et al., 1986 & $\mathrm{MC}-500$ & Building & $\begin{array}{l}\text { Medium - fine sand } \\
\text { with fines (6-18\%) }\end{array}$ & $\mathrm{S}$ \\
\hline Legendre et al., 1987 & Microsol & Oil well & Thin sand layer & $\mathrm{C}$ \\
\hline Brand et al., 1988 & $\mathrm{MC}-500$ & Landfill & Fine sand & $\mathrm{C}, \mathrm{S}$ \\
\hline Weaver et al., 1992 & MC-500 & Landfill & Branched dolomite & $\mathrm{C}$ \\
\hline Clarke et al., 1992 & MC-100+MC-300 & Dam & Branched rock mass & $\mathrm{C}$ \\
\hline Ballivy et al., 1997 & Spinor A12 & Tunnel & Gneiss and limestone & $\mathrm{S}$ \\
\hline Clarke et al., 1997 & $\begin{array}{l}\text { MC-100+MC-300 } \\
\text { MC-500 }\end{array}$ & Dam & Branched rock mass & $\mathrm{C}$ \\
\hline Van der Stoel, 1999 & Microcem & $\begin{array}{l}\text { Tunnels } \\
\text { subway }\end{array}$ & Sand layers & $\mathrm{S}$ \\
\hline \multirow{3}{*}{$\begin{array}{l}\text { Tolpannen and } \\
\text { Syrjanen, } 2003\end{array}$} & Ultrafin 12 & Coal storage & Rock mass & $\mathrm{C}, \mathrm{S}$ \\
\hline & Rheocem 900 & Gas storage & Rock mass & $\mathrm{C}, \mathrm{S}$ \\
\hline & Rheocem 650 & Athletic Center & Rock mass & $\mathrm{C}$ \\
\hline Pallardy et al., 2003 & Spinor A12 & Road tunnel & Rock mass & $\mathrm{C}$ \\
\hline Abreu et al., 2005 & MC $20 \mathrm{RS}$ & Bridge & Soil & $\mathrm{S}$ \\
\hline $\begin{array}{l}\text { Hognestad and } \\
\text { Frogner, } 2006\end{array}$ & Rheocem 800 & Railway tunnel & Hard rock mass (limestone) & $\mathrm{C}$ \\
\hline
\end{tabular}

*C: Groundwater control, \#S: improved strength of soil formation

\section{DISCUSSION AND CONCLUSIONS}

1) The improvement of properties and the mechanical behavior of soil formations can be achieved on the spot by performing an appropriate injection program. The injection program may: (a) be performed as a part of the preliminary field work prior to the commencement of a project's construction, (b) be a part of the construction of the main project, or (c) be designed and executed as a "treatment" when unforeseen circumstances arise during the construction of a project. 
2) Injections are generally intended either to increase the shear strength, density and stiffness of the soil or to reduce compressibility and permeability.

3) The grouts used to make permeation injections are mainly suspensions and chemical solutions.

4) The suspensions penetrate satisfactorily in soils with granulometry up to coarse sand.

5) Chemical solutions penetrate satisfactorily in more fine-grained formations up to fine-grained sands or coarsegrained sludges.

6) Because some chemical solutions are toxic or generally harmful to the environment and humans, an effort has been made internationally in recent years to replace them with inorganic fine-grained cement-based suspensions.

\section{REFERENCES}

[1] Philotheos Lokkas, Emmanouil Papadimitriou, Nikolaos Alamanis, Grigorios Papageorgiou, Dimitrios Christodoulou, and Theodoros Chrisanidis, "Significant Foundation Techniques for Education: A Critical Analysis", WSEAS Transactions on Advances in Engineering Education, doi: 10.37394/232010.2021.18.2., E-ISSN: 22243410, Vol. 18, pp. 7-26, 2021.

[2] Philotheos Lokkas, Ioannis Chouliaras, Theodoros Chrisanidis, Dimitrios Christodoulou, Emmanouil Papadimitriou, Evangelos Paschalis, "Historical background and evolution of Soil Mechanics", WSEAS Transactions on Advances in Engineering Education, DOI: 10.37394/232010.2021.18.10, E-ISSN: 2224-3410, Vol. 18, pp. 96-113, 2021.

[3] Nikolaos Alamanis, "Failure of Slopes and Embankments under Static and Seismic Loading", American Scientific Research Journal for Engineering, Technology and Sciences (ASRJETS), Vol. 35, No.1, pp. 95-126, 2017.

[4] Papageorgiou G.P., Alamanis N. and Xafoulis N., "Acceptable movements of road embankments", Electronic Journal of Structural Engineering, 20(1), pp. 30-32, Melbourne, Australia, 2020.

[5] Alamanis Nikolaos, Zografos Christos, Papageorgiou Grigorios, Xafoulis Nikolaos and Chouliaras Ioannis, "Risk of retaining systems for deep excavations in urban road infrastructure with respect to work staff perception", International Journal of Scientific \& Technology Research, Vol. 9, Issue 2, pp. 4168-4175, ISSN 2277-8616, 2020.

[6] Dimos Zachos, Georgios Bakalis, Konstantinos Bakalis, Nikolaos Alamanis, Grigorios Papageorgiou, Nikolaos Xafoulis, "A methodology for selecting the required cross-section of a self-supporting retaining bulkhead, on a vertical excavation front, of an energy conduit passage trench", Energy Systems, Springer https://doi.org/10.1007/s12667-021-00429-9, 2021.

[7] Alamanis N., Dakoulas P., "Simulation of random soil properties by the Local Average Subdivision method and engineering applications", Energy Systems, Springer. https://doi.org/10.1007/s12667-019-00362-y. Print ISSN 18683967, Online ISSN1868-3975 pp. 1-21, 2019.

[8] Alamanis N., Dakoulas P., "Effect of spatial variability of soil properties on permanent seismic displacements of slopes with uniform load", 14 ${ }^{\text {th }}$ Baltic Sea Geotechnical Conference, 18-19 Jan 2021, Helsinki, Finland, 2021.

[9] Atmatzidis D.K., "Soil improvements with injections", University Notes, University of Patras, Patras, Greece, 1990.

[10] Sudheer Kumar G., Sumanth M.K. and Madimi S., "A review paper on stabilization of sandy soil by using cement grouting technique”, Journal of Critical Reviews, Vol 7, Issue 14, ISSN- 2394-5125, pp. 902-908, 2020.

[11] Littlejohn S., "The development of practice in permeation and compensation grouting: A historical review (18022002): Part 1 Permeation Grouting", Proceedings of the $3^{\text {rd }}$ International Conference on Grouting and Ground Treatment, Johnsen F.L., Bruce A.D. and Byle J.M., Editors, New Orleans, La., U.S.A., ASCE, New York, U.S.A., Geotechnical Special Publication No. 120, Vol. 1, pp. 50-97, 2003.

[12] Van der Stoel A.E.C., "Grouting for pile foundation improvement", Ph.D. Thesis, Technische Universiteit Delft, Published and Distributed by: DUP Science, 2001.

[13] Karol R.H., "Grout penetrability", Proceedings, Issues in Dam Grouting, Baker W.H., Editor, Denver, Colorado, U.S.A., ASCE, New York, U.S.A., pp. 27-33, 1985.

[14] Karol R.H., "Chemical grouts and their properties", Proceedings, Conference on Grouting in Geotechnical Engineering, Baker W.H., Editor, New Orleans, Louisiana, U.S.A., ASCE, New York, U.S.A., Vol. 1, pp. 359-377, 1982.

[15] Saada Z., Canou J., Dormieux L., Dupla J.C. and Maghous S., "Modelling of cement suspension flow in granular porous media", International Journal for Numerical and Analytical Methods in Geomechanics, Vol. 27, Issue 7, pp. 691-711, 2005.

[16]Bruce A.D., Littlejohn S. and Naudts C.A., "Grouting materials for ground treatment: A practitioner's guide", Proceedings, Conference on Grouting: Compaction, Remediation, Testing, Vipulanandan C., Editor, Logan, Utah, U.S.A., ASCE, New York, U.S.A., Geotechnical Special Publication No. 66, pp. 306-334, 1997.

[17] Arenzana L., Krizek R.J. and Pepper S.F., "Injection of dilute microfine cement suspensions into fine sands", Proceedings of the International Conference on Soil Mechanics and Foundation Engineering, A.A. Balkema, Rotterdam, The Netherlands, Vol. 2, pp. 1331-1334, 1989.

[18]Eriksson M. and Stille H., "A method for measuring and evaluating the permeability of grouts", Proceedings of the $3^{\text {rd }}$ International Conference on Grouting and Ground Treatment, Johnsen F.L., Bruce A.D. and Byle J.M., Editors, New Orleans, U.S.A., ASCE, New York, U.S.A., Geotechnical Special Publication No. 120, Vol. 2, pp. 1326-1337, 2003. 
[19] Weaver K.D., "Dam Foundation Grouting”, ASCE, New York, U.S.A., 1991.

[20] Sideris K., "Technology of building materials", Volume 1, University Notes, Department of Civil Engineering, Democritus University of Thrace, Xanthi, Greece, 1998.

[21] Markou I.N., "Grinded Greek lignite fly ash as a suspension-type injection material for on-site soil improvement reinforcement", PhD Thesis, Department of Civil Engineering, University of Patras, Greece, 1995.

[22] Littlejohn G.S., "Design of cement-based grouts", Proceedings, Conference on Grouting in Geotechnical Engineering, Baker W.H., Editor, New Orleans, Louisiana, U.S.A., ASCE, New York, U.S.A., Vol. 1, pp. 35-48, 1982.

[23] Tolpannen P. and Syrjanen P., "Hard rock tunnel grouting practice in Finland, Sweden, and Norway: Literature study", Technical Report, Finnish Tunnelling Association, 2003.

[24] Naudts A., Landry E., Hooey S. and Naudts W., "Additives and admixtures in cement-based grouts", Proceedings of the 3rd International Conference on Grouting and Ground Treatment, Johnsen F.L., Bruce A.D. and Byle J.M., Editors, New Orleans, La., U.S.A., ASCE, New York, U.S.A., Geotechnical Special Publication No. 120, Vol. 2, pp. 1180-1191, 2003.

[25]Legendre Y., Hery Ph. and Vattement H., "Microsol grouting, A method for grouting fine alluvium", Proceedings, 6th International Conference Offshore Mechanics and Arctic Engineering Symposium, Houston, Texas, U.S.A., ASCE, New York, U.S.A., Vol. 1, pp. 433-440, 1987.

[26] Shimoda M. and Ohmori H., "Ultrafine grouting material", Proceedings, Conference on Grouting in Geotechnical Engineering, Baker W.H., Editor, New Orleans, Louisiana, U.S.A., ASCE, New York, U.S.A., Vol. 1, pp. 77-91, 1982.

[27] Dupla J.-C., Canou J. and Gouvenot D., “An advanced experimental set-up for studying a monodirectional grout injection process", Ground Improvement, Thomas Telford Ltd, Vol. 8, No. 3, pp. 91-99.

[28] Clarke W.J., (1984), "Performance characteristics of microfine cement", ASCE Preprint 84-023, Atlanta, Ga., U.S.A., pp. 1-14, 2004.

[29] Dano C. and Hicher P.Y. and Tailliez S., "Engineering properties of grouted sands", Journal of Geotechnical and Geoenvironmental Engineering, ASCE, New York, U.S.A., pp. 328-338, 2004.

[30] Christodoulou D.N., Droudakis A.I., Pantazopoulos I.A., Markou I.N. and Atmatzidis D.K., "Groutability and Effectiveness of Microfine Cement Grouts", Proceedings, 17th International Conference on Soil Mechanics and Geotechnical Engineering: The Academia and Practice of Geotechnical Engineering, Alexandria, Egypt, Hamza et al. (Editors), IOS Press, Vol. 3, pp. 2232-2235, 2009.

[31] Pantazopoulos I.A., Markou I.N., Christodoulou D.N., Droudakis A.I., Atmatzidis D.K., Antiohos S.K. and Chaniotakis E., "Development of microfine cement grouts by pulverizing ordinary cements", Cement and Concrete Composites, 34(5), pp. 593-603, 2012.

[32] Markou I.N., Christodoulou D.N., Petala E.S. and Atmatzidis D.K., "Injectability of Microfine Cement Grouts into Limestone Sands with Different Gradations: Experimental Investigation and Prediction", Geotechnical and Geological Engineering Journal, Vol. 36, Issue 2, pp. 959-981, 2018.

[33] Markou I.N., Christodoulou D.N. and Papadopoulos B.K., "Penetrability of microfine cement grouts: experimental investigation and fuzzy regression modeling”, Canadian Geotechnical Journal, 52(7), pp. 868-882, 2015.

[34] Mollamahmutoglu M., "Treatment of medium to coarse grained sands by fine grained Portland cement (FGPC) as an alternative grouting material to silicate-ester grouts", Cement, Concrete and Aggregates, 25(1), pp. 1-6, 2003.

[35] Perret S., Palardy D. and Ballivy G., "Rheological behavior and setting time of microfine cement-based grouts", ACI Materials Journal, Vol. 97, No. 4, pp. 472-478, 2000.

[36] Huang Z., Chen M. and Chen X., "A developed technology for wet-ground fine cement slurry with its applications", Cement and Concrete Research, Elsevier Science Ltd, Vol. 33, pp. 729-732, 2002.

[37] De Paoli B., Bosco B., Granata R. and Bruce D.A., "Fundamental observations on cement based grouts (2): Microfine cements and the Cemill process", Proceedings, Conference on Grouting, Soil Improvement and Geosynthetics, Borden R.H., Holtz R.D. and Juran I., Editors, New Orleans, Louisiana, U.S.A., ASCE, New York, U.S.A., Geotechnical Publication No. 30, Vol. 1, pp. 486-499, 1992b

[38] Ahrens H.E., “A new and superior ultrafine cementitious grout”, Proceedings, Conference on Grouting: Compaction, Remediation, Testing, Vipulanandan C., Editor, Logan, Utah, U.S.A., ASCE, New York, U.S.A., Geotechnical Special Publication No. 66, pp.188-196, 1997.

[39] Naudts A. and Landry E., "New on-site wet milling technology for the preparation of ultrafine cement-based grouts", Proceedings of the 3rd International Conference on Grouting and Ground Treatment, Johnsen F.L., Bruce A.D. and Byle J.M., Editors, New Orleans, La., U.S.A., ASCE, New York, U.S.A., Geotechnical Special Publication No. 120, Vol. 2, pp. 1200-1207, 2003.

[40] Bruce D.A., "Trends and developments in American grouting practice", Proceedings, Conference on Grouting in the Ground, Bell A.L., Editor, London, England, Thomas Telford, London, England, pp. 573-589, 1992.

[41] Henn R., Ganse P., Bandimere S., Smoak G. and Warner J., "Comparison of penetration test results of grouts made with various ultrafine cement products", Proceedings of the Rapid Excavation and Tunneling Conference, Elsevier Science B.V., Amsterdam, pp. 345-361, 2001. 
[42]Henn R. and Davenport R., "Ultrafine cement: A critical component of a grouting program”, Tunnels and Tunnelling International, pp. 27-29, 2005.

[43] Brachman R.W.I., Martin C.D. and Gilliss S.A., "Grout field trials in outwash sands", Canadian Geotechnical Journal, Vol. 41, No. 1, pp. 1-11, 2004.

[44] Clarke W.J., Boyd M.D. and Helal M., "Ultrafine cement tests and dam test grouting", Proceedings, Conference on Grouting, Soil Improvement and Geosynthetics, Borden R.H., Holtz R.D. and Juran I., Editors, New Orleans, Louisiana, U.S.A., ASCE, New York, U.S.A., Geotechnical Publication No. 30, Vol. 1, pp. 626-638, 1992.

[45] Clarke W.J., Boyd M.D. and Helal M., "Ultrafine cement tests and drilling Warm Spring Dam", Proceedings, Geotechnical Practice in Dam Rehabilitation, Specialty Conference, Anderson L.R., Editor, Raleigh, North Carolina, U.S.A., ASCE, New York, U.S.A., Geotechnical Publication No. 35, pp. 718-732, 1993.

[46] Clarke W.J. and McNally A.C., "Ultrafine cement for oilwell cementing", Rocky Mountain Regional Meeting/Low Permeability Reservoirs Symposium and Exhibition, Denver, CO, U.S.A., Society of Petroleum Engineers (SPE), Richardson, TX, United States, pp. 291-298, 1993.

[47] Weaver K., Coad R.M. and McIntosh K.R., "Grouting against hazwaste”, Civil Engineering, ASCE, New York, U.S.A., Vol. 62, No. 5, pp. 70-72, 1992a.

[48] Helal M. and Krizek R.J., "Preferred orientation of pore structure in cement-grouted sand", Proceedings, Conference on Grouting, Soil Improvement and Geosynthetics, Borden R.H., Holtz R.D. and Juran I., Editors, New Orleans, Louisiana, U.S.A., ASCE, New York, U.S.A., Geotechnical Publication No. 30, Vol. 1, pp. 526-540, 1992.

[49] Schwarz L.G. and Krizek R.J., "Effects of mixing on rheological properties of microfine cement grout", Proceedings, Conference on Grouting, Soil Improvement and Geosynthetics, Borden R.H., Holtz R.D. and Juran I., Editors, New Orleans, Louisiana, U.S.A., ASCE, New York, U.S.A., Geotechnical Publication No. 30, Vol. 1, pp. $512-525,1992$.

[50] www.parchem.com.au

[51] Bouchelaghem F. and Vulliet L., "Mathematical and numerical filtration-advection-dispersion model of miscible grout propagation in saturated porous media", International Journal for Numerical and Analytical Methods in Geomechanics, John Wiley \& Sons, Ltd., Vol. 25, pp. 1195-1227, 2001.

[52] Abreu J.V., Mezzalira F.A. and Cruz L.O.M., "Brazilian special cements for shotcrete and injections in underground constructions", Proceedings, Conference on Waterproofing, ITA-AITES, Sao Paulo, Brazil, 2005.

[53] Hakansson U., Hassler L. and Stille H., "Rheological properties of microfine cement grouts with additives", Proceedings, Conference on Grouting, Soil Improvement and Geosynthetics, Borden R.H., Holtz R.D. and Juran I., Editors, New Orleans, Louisiana, U.S.A., ASCE, New York, U.S.A., Geotechnical Publication No. 30, Vol. 1, pp. 551-563, 1992.

[54] Reinhardt H.W., "Ultra-fine cements for special applications”, Advanced Cement Based Materials, Vol. 1, pp. 106107, 1993.

[55] Mittag J. and Savvidis S., "The groutability of sands - results from one-dimensional and spherical tests", Proceedings, $3^{\text {rd }}$ International Conference on Grouting and Ground Treatment, Johnsen F.L., Bruce A.D. and Byle J.M., Editors, New Orleans, La., U.S.A., ASCE, New York, U.S.A., Geotechnical Special Publication No. 120 , Vol. 2, pp. 1372-1382, 2003.

[56] Mollamahmutoglu M., Yilmaz Y. and Kutlu I., "Grouting performance of microfine cement and silica fume mix into sands”, Journal of ASTM International, Vol. 4, Issue 4, 2007. 